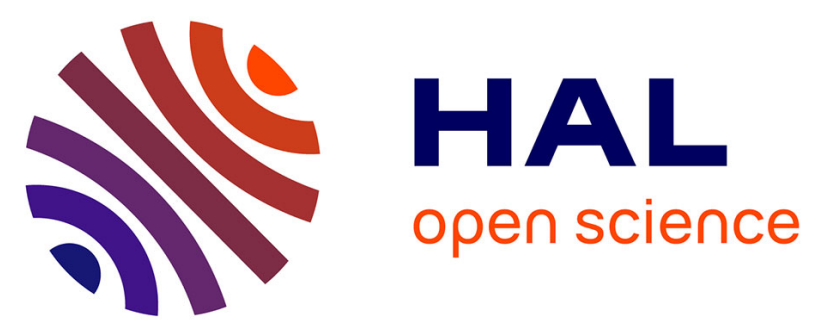

\title{
Effect of different management systems on rutting behavior and behavioral repertoire of housed Maghrebi male camels (Camelus dromedarius).
}

Meriem Fatnassi, Barbara Padalino, Davide Monaco, Lydiane Aubé, Touhami Khorchani, Giovanni Michele Lacalandra, Mohamed Hammadi

\section{To cite this version:}

Meriem Fatnassi, Barbara Padalino, Davide Monaco, Lydiane Aubé, Touhami Khorchani, et al.. Effect of different management systems on rutting behavior and behavioral repertoire of housed Maghrebi male camels (Camelus dromedarius).. Tropical Animal Health and Production, 2014, 46 (5), pp.861-7. 10.1007/s11250-014-0577-6 . hal-01068726

HAL Id: hal-01068726

https://hal-univ-rennes1.archives-ouvertes.fr/hal-01068726

Submitted on 26 Sep 2014

HAL is a multi-disciplinary open access archive for the deposit and dissemination of scientific research documents, whether they are published or not. The documents may come from teaching and research institutions in France or abroad, or from public or private research centers.
L'archive ouverte pluridisciplinaire HAL, est destinée au dépôt et à la diffusion de documents scientifiques de niveau recherche, publiés ou non, émanant des établissements d'enseignement et de recherche français ou étrangers, des laboratoires publics ou privés. 
Effect of different management systems on rutting behavior and behavioral repertoire of housed Maghrebi male camels (Camelus dromedarius)

\section{Meriem Fatnassi ${ }^{1}$, Barbara Padalino ${ }^{2 *}$, Davide Monaco ${ }^{3}$, Lydiane Aubé ${ }^{4}$, Touhami Khorchani ${ }^{1}$, Giovanni Michele Lacalandra ${ }^{3}$, Mohamed Hammadi ${ }^{1}$}

${ }^{1}$ Livestock and Wildlife Laboratory, Arid Lands Institute, 4100 Medenine, Tunisia

${ }^{2}$ Department of Veterinary Medicine, University of Bari, Str. prov. Per Casamassima, km 3, 70010 Valenzano (Bari), Italy

${ }^{3}$ Department of Emergency and Organ Transplantation, University of Bari (D.E.T.O.), Veterinary Clinics and Animal Production Section, Str. prov. Per Casamassima, km 3, 70010 Valenzano (Bari), Italy

${ }^{4}$ Laboratoires d'Ethologie Animale et Humaine EthoS -University of Rennes, Campus de Beaulieu, Rennes, France

*Corresponding author:

Barbara Padalino

Department of Veterinary Medicine, University of Bari, Str. prov. Per Casamassima, km 3, 70010 Valenzano (Bari), Italy

Tel. 00390805443935

Fax. 00390805443925

E-mail: barbara.padalino@uniba.it 


\begin{abstract}
Camel management has been changing in recent years from an extensive to a semi-intensive or intensive system, particularly for breeding bulls and dairy dromedary camels. Captivity may affect animal welfare, and low libido is the major complaint for housed breeding bulls. Since welfare status could also affect reproductive performance, the aim of this study was to evaluate different management practices on behavior, particularly on sexual behavior, and to identify some behavioral needs of male dromedary camels reared for semen collection. The effects of the following management systems on their behavior were compared: i) traditional: housing in a single stall for 24 hours (H24), ii) housing in a single stall for 23 hours with one hour free in the paddock (H23) and iii) housing in a single stall for 22 hours and 30 min with $1 \mathrm{~h}$ paddock time and $30 \mathrm{~min}$ exposure to a female camel herd (ExF). During the trial, blood cortisol concentrations were assessed and camels werefilmed dailyfor thirty minutes in the mornings and during a female passage in the evenings. Videos were analyzed in order to fill out a focal sampling ethogram and to score sexual behavior. As a result, there were no differencesbetweenthe $\mathrm{H} 24$ and $\mathrm{H} 23$ systems, whereas ExF had a significant positive impact ontheir sexual behavior score and behavioral repertoire, further reducing cortisol levels. Overall, it seems that male dromedary camel welfare status improves when theirbehavioral needs for social interaction and movement are satisfied.
\end{abstract}

Keywords: dromedary camel, husbandry, sexual behavior, cortisol, welfare. 


\section{Introduction}

Camels (Camelus dromedarius) are seasonal breeders, with mating occurringduring the coolest months of the year; indeed,thisshort breeding season is one of the main factors limiting reproductive performance (Vyas et al. 2001). Consequently, male camel husbandry has recently been changing towards a more intensive system where they are kept isolated and used for programmed mating or artificial insemination (Skidmore et al. 2013).

During the breeding season, male camels exhibit morphological, behavioral and endocrinological peculiarities, increasing pacing and anxiety and becoming extremely restless and aggressive (Deen 2008). Due to this aggressiveness toward other males and humans, rutting camels are traditionally reared tied with ropes in little pensand/or kept in single stalls (Abu-Zidan et al. 2012).

Captivity imposes different kind of constraints on the animal (e.g. limited space, social isolation) that could affectits behavioral repertoire and welfare status (Dawkins 2003; Christie et al. 2006). Under intensive management, animals are in fact confronted with a wide range of potentially provocative environmental challenges (potential stressors) that may adversely affect the animal's life (Morgan and Tromborg 2007). During stress conditions, blood glucocorticoid levels increase and this could impair reproductive aspectssuch as libido and fertility (Phillips et al. 1989, Orr et al. 1994, Wingfield and Sapolsky 2003).

A feral camel bull would naturally roam wide areas of land, moving over pastures with his female herd (Dörges et al. 1992), by contrast,a camel bull, kept in isolation during intensive management, could show abnormal behaviors (Padalino et al. 2014). In addition, male camels show earlier sexual behavior and higher mating ability under field conditions, compared with housed males (Abdel Rahim \& Nazier, 1992). Consequently, the major complaints for housed camels bred for semen collection are low libido and mating desire, short breeding season and high variability in terms of semen quality and quantity (El-Hassanein 2003; El-Bahrawy 2005).

Low sexual libido is also a common complaint in breeding stallions, if they are bred in poor welfare conditions (Stout 2005). Davies Morel (2003) stated that suchlow reproductive performances could be overcome by alleviating boredom, providing social interaction and exercise. Indeed, it had already been proved that basic fitness and muscle tone aids in maintaining the physical and psychological well-being of a stallion, with positive effects on libido, performance and behavior (Dinger and Noiles 1986). Moreover, McDonnel (2000) suggested that placing the stallion under natural light, with the chance to get both exercise and social interaction with mares, could improve reproductive efficiency and fertility, overcoming specific breeding problems.

The effect of management on sexual behavior has been poorly investigated in camels, except by Vyas et al. (2001) and Bhakat et al. (2005) who first proposed a method for augmenting the rut of male camels, out of the breeding season, byparading the male sire in front of the female herd. 
Hypothesizing that management practices and sexual arousal of bulls could influence their welfare and libido, the aim of this study was to evaluate the effect of three different management practices on behavior, particularly on sexual behavior, and to begin the process of identifying the behavioral needs of Maghrebi male dromedary camels reared for semen collection.

\section{Material and Methods}

\section{Animals and management systems}

Four clinically healthy male dromedary camels (Camelus dromedarius), ranging in age from 5 to 8 years, with a mean body weight $(\mathrm{BW})$ of $526 \pm 25 \mathrm{~kg}$ and good body condition score $(\mathrm{BCS}=3.5 \pm 0.3$ arbitrary units; from 0 to 5 according to Faye et al. (2001)) and one non-pregnant female camel (10 years old, $420 \mathrm{~kg} \mathrm{BW}$, and 3.0 BCS) were used for this study. All animals were identified by ear tags. The camels had been reared at the Arid Lands Institute's experimental station in Médenine, Tunisia (333 $\left.30^{\prime} \mathrm{N}, 10^{\circ} 40^{\prime} \mathrm{E}\right), 18 \mathrm{~m}$ above sea level.

In summer, the bulls were kept in a single open-air paddock shaded by trees whereas, starting fromOctober, before the beginning of the breeding season, they were put into single stalls (Height $=3 \mathrm{~m}$, Length $=5 \mathrm{~m}$ and Width $=3 \mathrm{~m}$ ) with sand floors. They were tethered with a rope on the fetlock of the foreleg and were able to walk around inside the stall. The stalls were located far from the females' pen, preventing them from seeing and touching any dams; the gates of the stable pointed eastwards, facing an open-air paddock and with small windows on the opposite wall.

During this trial, the male dromedary camels were randomly tested in three different management systems: i) traditional: housed in single stalls for the whole day (H24), ii) housed in the same stall for 23 hours, plus 1 hour free in a paddock (H23) or iii) housed in the same stall for 22 hours and $30 \mathrm{~min}$, with 1 hour of paddock time and 30 min from 8:00 to 8:30 a.m. in a little pen adjacent to the female herd's pen (ExF). The paddock lies in front of the stable where the stalls are located and measures $250 \mathrm{~m}^{2}$, whereas the little pen adjacent to the female herd's pen measures $150 \mathrm{~m}^{2}$ and is bordered by a $130 \mathrm{~cm}$-high wall dividing the two pens. Females were free to move and to touchthe males with their heads.

One hour of paddock time was chosen, as set out in a study by Freire et al. (2009) who proved that one hour or regular exercise in a paddock has positive effects on horse welfare. Moreover, 30 minutes of exposureto females had already been adopted by Bhakat et al. (2005) to enhance the male camel breeding season.

Each experimental condition lasted 7 days and was preceded by a habituation week, so the whole trial lasted six weeks (three weeks for the habituation period and three weeks of experimental situations), from the middle to the end of the breeding season. 
The camels were fed daily with $5 \mathrm{~kg}$ oat hay at 9:00 a.m. and $3 \mathrm{~kg}$ concentrate supplement based on barley (60.0\%), wheat bran (17.5\%), olive cake (17.5\%) and a mineral and vitamin complex (5.0\%) at 3:00 p.m. (Table 1). Feeding quantity and quality remained constant throughout the experiment. The diet met the maintenance requirements as set by Laudadio et al. (2009), and water was made available once every two days.

During the trial, the bulls were used for semen collection twice weekly. They were well accustomed to this practice and to the traditional husbandry system, so we only changed the management system in accordance with the experimental protocol.

The entire study was performed in accordance with the ethical standards laid down in the 1964 Declaration of Helsinki and its later amendments. No special permission for behavioral research on wild animals such as this study is required in Italy.

\section{Behavioral parameters and processing}

In each management system, the four males were filmed by a video-camera (Sony Camcorder digital video) for30 min every morning at the same time from 8:00 to 8:30 a.m. for 7 days in each experimental condition, without being disturbed by the operator. Moreover, during each experimental condition every day (Monday to Sunday) at 6:30 p.m., the female camel was used to evaluate the sexual behavior of captive males according to Padalino et al. (2013); the female camel was brought into the paddock in front of the males'stalls and placed with her rear end attached to the gate of each sire. During the parade, the male was able to reach and smell/touch the female's perineumwith his nose. The female was presented to each male, sire by sire, for $4 \mathrm{~min}$; the first parade lasted 16 min in overall, and three parades were performed daily for a total of $48 \mathrm{~min}$.

The videos were recorded every morning for $30 \mathrm{~min}$, and then analyzed by two expert ethologists, who filled out a focal animal sampling ethogram, defined as the sampling method whereby the recorder chooses one individual and records all behaviors performed by the individual in a specified time window (Altmann 1974). The duration of the following behavioral states was noted down: feeding, rumination, resting, standing, walking and looking outside. The occurrence of the following behavioral events was also recorded: leg movements, number of steps, sound emission, defecation, urination, tail flapping, opened legs, yawning, teeth grinding, blatering, sniffing and flehmen.

Moreover, while watching the videos of the female parades, the two experts scored the male camel sexual behavior (Table. 2) in accordance with the method proposed by Padalino et al. (2013) and subsequentlyused by Fatnassi et al. (2013).

\section{Blood sampling and analysis}


On Monday and Thursday of each experimental week, blood samples were collected by the same operator to evaluate cortisol concentration, while camels were in resting condition in their stalls. Blood samples were collected from the jugular vein under aseptic conditions directly into Venoject@ tubes (Terumo Europe N. V. 3001 Leuven, Belgium) with lithium heparin and were kept in ice until plasma was separated within $2 \mathrm{~h}$ of collection by centrifugation at $4^{\circ} \mathrm{C}$ for 15 min at $3000 \mathrm{rpm}$. Plasma samples were stored at $-20^{\circ} \mathrm{C}$ until analyzed.The plasma cortisol concentration was assessed in duplicate by Liquid chromatography-mass spectrometry (LC/MS).

\section{Statistical analyses}

Data were normally distributed. Cortisol concentrations were statistically analyzed through an analysis of variance using the Generalized Linear Model (GLM) procedure (SAS, version 9, 1999), where the independent variable was the management system $(\mathrm{H} 24, \mathrm{H} 23, \mathrm{ExF})$. By contrast, the data related to behavioral parameters (both duration and occurrence) and sexual behavioral score were subjected to repeat measures of analysis of variance using the GLM procedure (SAS, version 9, 1999). The independent variables were the management system $(\mathrm{H} 24, \mathrm{H} 23$, ExF), the period of observation (from Monday to Sunday) and the interaction between those variables. Tukey's post hoc test was used to perform statistical multiple comparison. The $p$-level was set at 0.05 . All data were expressed as quadratic mean and mean standard error.

\section{Results}

Cortisol concentration slightly decreased among the three different management systems (H24: 18.8 $\pm 2.0 ; \mathrm{H} 23: 15.9 \pm$ 2.0; ExF: $14.1 \pm 2.0 \mathrm{ng} / \mathrm{ml})$, but there was no statistical difference $(\mathrm{df}=2 ; \mathrm{F}=1.27 ; \mathrm{P}=0.3)($ Fig. 1).

No significant difference was observed in any parameter for day (from the first to the seventh day of the week) (df $=6$; $\mathrm{F}=1.53 ; \mathrm{P}=0.18)$ and in the interaction between day and experimental condition $(\mathrm{df}=12 ; \mathrm{F}=1.82 ; \mathrm{P}=0.06)$. On the other hand, the effect of the experimental condition was significant $(\mathrm{df}=2 ; \mathrm{F}=116.30 ; \mathrm{P}<0.0001)$. Concerning the duration of the behavioral pattern, there was no difference among the first and the second management system, but both were significantly different from the third (feeding $\mathrm{P}=0.0004$; rumination $\mathrm{P}<0.0001$; standing $\mathrm{P}<0.0001$; walking $\mathrm{P}$ $<0.0001)$, except for resting that was not significant $(\mathrm{H} 24: 10.0 \pm 5.9 ; \mathrm{H} 23: 13.8 \pm 5.9 ; \mathrm{ExF}: 0.1 \pm 5.9 \mathrm{sec} ; \mathrm{P}=1.0)$.

Under ExF, during morning observation, males spent most of the time looking outside at the females $(\mathrm{P}<0.0001)($ Fig. 2).

Regarding the frequency of behavioral patterns studied (Table 3), as camels were more active and stimulated in ExF, the occurrence of all the events was significantly higher in ExF compared with $\mathrm{H} 24$ and $\mathrm{H} 23$ ( $\mathrm{P}<0.01)$.

Finally, the sexual behavior score (SBS) was also affected by management system; during the ExF week, the average SBS was $3.2 \pm 0.1$, significantly higher than for $\mathrm{H} 24(2.7 \pm 0.1 ; \mathrm{P}=0.02)$ and $\mathrm{H} 23(2.8 \pm 0.1 ; \mathrm{P}=0.02)($ Fig. 3$)$. 


\section{Discussion}

In the present study, we compared the effects of three housing systems on male camel physiology and sexual behavior. It is well documented that welfare status can be assessed by four broad criteria: behavior, physiology, health and production (Dawkins 2003), while it is also known that animals housed in artificial habitats are confronted by a wide range of potentially provocative environmental challenges that could affect their endocrine system (Morgan and Tromborg, 2007). Camels housed all daylong in single stalls (H24) reported a blood cortisol concentration twice the normal value range, as previously reported in Indian male dromedary camelsby Kataria and Kataria (2010) and Kataria et al. (2010). This is likely due to the traditional husbandry system (H24) being more stressful for the animals. Nevertheless, cortisol concentration showed a downward trend from $\mathrm{H} 24$ to ExF, indicating that both freedom of movement in an open paddock (H23) and the freedom to express normal social behavior,interacting with females (ExF), had a positive impact, alsoon the animals' well-being. This is in accordance with McGlone et al. (2004) who reported that cortisol concentrations were higher in gestating sows kept in stalls compared with those housed in pens. It is also noteworthy that the level of blood cortisol in male camels reared in the ExF system became more similar to those reported by Bhakat et al. (2005) for male dromedary camels exposed to females during the Indian rutting season.

Underthe H24 and H23 systems, the animals spent the majority of their time ruminating, standing and feeding. Rumination is an important health indicator and thus it is important for welfare (Schwan 2011) but it was also defined by Hoyer (2013) as an anti-boredom activity caused by captivity and social isolation. In ExF, a significant change in behavior repertoire was observed: the camels showed a reduction in feeding and rumination duration and an increase in walking and looking at females. This is in agreement with Bhakat et al. (2005), who reported that, compared with unexposed one,a male camel regularly exposed to a female showed a significant reduction in dry matter and water intake and a decrease in body weight. Due to the feed intake reduction and the energy spent in mating activities, male camels have usually become underweight by the end of the breeding season (El-Wishy 1988; Skidmore 2000; Khan et al. 2003).

The behavioral repertoire changed significantly among the three different management systems, which could be explained by the presence of the females, stimulating the natural sexual behavior of the rutting males. During the rutting season, feral bulls show an increase in anxiety and restlessness and spend most of their time guarding the herd and surveying the fence line to prevent intrusion by other males. Similar behaviors were observed in harem stallions which spend most of their time guarding the harem fence line area, with their attention apparently focused on the mares in nearby pastures, aggressively evicting intruders, and periodically harassing bachelor stallions (McDonnell 2000).

The increased mobility caused the significant difference in the occurrence of leg movements and number of steps between the different rearing systems. It should be underlined, in any case, that the frequency of all recorded events was 
lower in $\mathrm{H} 24$ and $\mathrm{H} 23$ than in ExF, likely because the presence of the female induced and stimulated the males to express their normal sexual behavior.Male dromedary camel sexual behavior is characterized by species-specific behaviors, such as open leg standing, tail flapping, blatering, dulaa extrusion and emission of metallic sounds(Skidmore 2000). In camels, pheromones are present in rutting male urine, and Skidmore (2000) observed that urine spraying generally increases in the presence of another male or when females are passing nearby. Thus, as expected, urination and defecation occurrence was higher in ExF, becausethey are markers indicating the male's presence to establish his territoriality.McDonnell (1986) stated that in stallions repeated defecation, particularly near the fence line, is a common behavior of the stud and that it results in accumulation of fecal matter into large mounds, known as "stud piles". Tail flapping frequency also increased in ExF, because this behavior usually accompanies urination, and is also used as a sign of marking, dominance and sexual excitability.

Underthe ExF system, camels also frequentlydisplayed teethgrinding, associated with an increase in salivary gland secretionandsound emissions, as the male's excitement increased and more auditory signals were producedto attract the females (Bhakat et al. 2005).Flehmen occurrence also increased, as observed in other species. Indeed, sniffing, licking and nuzzling of the female's genitalia are the most frequent patterns in sexually active stallions (McDonnell 2000), but flehmen is also normal behavior in cow-bull courtship (Bailey et al. 2005).

The lower expression of mentionedsexual behaviorsin H24 and H23 systems could indicate a lack of sexual stimuli. The traditional husbandry system (H24) seems not to meet the animal's behavioral needs, and this could be the reason for the low mating desire and reproductive performance lamented by El-Hassanein (2003) and El-Bahrawy (2005) in their male camels bred for semen collectionin $\mathrm{H} 24$.

Nevertheless, it is often assumed that for welfare purposes, farm animals should be given "the freedom to express their natural behaviors" (Spinka 2006). Haskell et al. (2013) showed that when cows are housed in open areas they are able to express their natural behaviors more easily than in confined spaces, andour data reported a similar situation also in camels.Thus, when the housing condition metan animal's needs, itspsychological and physiological status improved, with a positive knock-on effect on sexual behavior; in fact,the camel's sexual behavior score was significantly higher in ExF than in $\mathrm{H} 24$ and $\mathrm{H} 23$.

The rise in the sexual behavioral score demonstrates that improved management, more compliant with the camel's behavioral needs, exerts a long-term effect on the animal's physiological status. The interactionsbetween the hypothalamic-pituitary-adrenal (HPA) and the hypothalamic-pituitary-gonadal (HPG) are well noted: stress response negatively affected sexual behavior (Rivier and Riviest, 1991; Retana-Márquez et al., 2003; Kirby et al., 2009). Therefore, we can suppose that, since stress activity decreased in H23 and ExF, HPG activity was stimulated, leading to more intense expression of the male camels' rutting signs. 


\section{Conclusion}

Overall, this study demonstrated that traditional management (H24) negatively affects male camels'sexual behavior, also leading to increased production of cortisol. From our preliminary data, it seems that the management system that allows movements and interaction with females $(\mathrm{ExF})$ had a positive impact on camel rutting behavior and welfare. We therefore hypothesize that freedom to move and to express social behavior are behavioral needs in camels reared for semen collection, ensuring their well-being. However, further studies are needed to investigate the effects of the ExF system on camel libido and semen quality.

\section{Acknowledgments}

The authors are grateful to the Tunisian authorities and thank all the technicians at the Livestock and Wildlife Laboratory for their valuable help during this study.The authors would also like to thank dr. Anthony Green for kindly suggesting stylistic improvements to the text

\section{Disclosure}

This document has been produced with the financial assistance of the European Union through the "PROCAMED" Project: Promotion des systèmes camelins innovants et des filières locales pour une gestion durable des territoires saharienne: reference number: I.B/1.1/493. The contents of this document are the sole responsibility of the Livestock and Wildlife Laboratory, IRA Médenine, Tunisia and Veterinary Clinics and Animal Productions Unit D.E.T.O. Bari, Italy, and can under no circumstances be regarded as reflecting the position of the European Union.

\section{Conflict of interest}

The authors declare that they have no conflict of interest.

\section{References}

Abdel Rahim, S. and El Nazier, A.T., 1992. Studies on the sexual behavior of the dromedary camel.In:Allen W.R.,

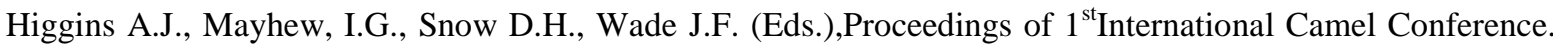
R \& W Publications(Newmarket) Ltd., UK, 115--118

Abu-Zidan, F.M., Eid, H.O., Hefney, A.F., Bashir, M.O., Branicki, F., 2012. Camel bite injuries in United Arab Emirates: A 6 years prospective study, Injury, 43, 1617--1620

Altmann, J., 1974. Observational study of behavior: sampling methods. Behavior, 49, 227--265

Bailey, J.D., Anderson, L.H. and Schillo, K.K., 2005. Effects of novel females and stage of the estrous cycle on sexual behavior in mature beef bulls, Journal of Animal Science, 83, 613--624 
Bhakat, C., Raghavendra, S. and Sahani, M.S., 2005. Effect of different management conditions on rutting behavior of Indian dromedary camel, Emirates Journal of Food and Agriculture, 17, 1--13

Christie, J.L., Hewson, C.J., Riley, Ch.B., McNiven, M.A., Dohoo, I.R., Bate, L.A., 2006. Management factors affecting stereotypies and body condition score in non-racing horses in Prince Edward Island, Canadian Veterinary Journal, 47, 136--143

Davies Morel, M.C.G., 2003. Stallion Management. Equine Reproductive Physiology, Breeding and Stud Management. 2nd Edition,(CABI Publishing New York)

Dawkins, MS., 2003. Behaviour as a tool in the assessment of animal welfare, Zoology, 106, 383--7

Deen, A., 2008. Testosterone profiles and their correlation with sexual libido in male camels, Research in Veterinary Science, 85, 220--226

Dinger, J.E. and Noiles, E.E., 1986. Effect of controlled exercise on libido in 2 yr old stallion, Journal of Animal Science, 62, 1220--1223

Dörges, B., Heucke, J. and Klingel, H., 1992. Behaviour and social organization of feral camels in Central Australia. In:

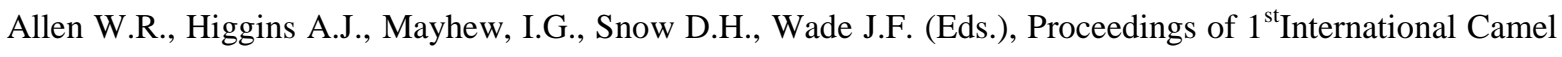
Conference. R \& W Publications (Newmarket) Ltd., UK, 317-318

El-Bahrawy, K.A., 2005. Reproductive Studies on Desert Animals: Sexual Behaviour and Semen Characteristics and Freezability of Male Dromedary Camels,(unpublished PhD thesis, Alexandria University Egypt)

El-Hassanein, E., 2003. An invention for easy semen collection from dromedary camels, El- Hassanein camel dummy. In: Recent advances in camelid reproduction. Skidmore J.A. and Adams,G.P., (eds), (Publisher: International Veterinary Information Service, Ithaca, New York, USA)

El-Wishy, A.B., 1988. Reproduction in the male dromedary (Camelus dromedarius): a Review, Animal Reproduction Science, 17, 217--241

Fatnassi, M., Padalino, B., Monaco, D., Khorchani, T., Lacalandra, G.M. and Hammadi, M., 2013. Evaluation of sexual behavior of housed male camels (Camelus dromedarius) through female parades: correlation with climatic parameters, Tropical Animal Health and Production, Doi: 10.1007/s11250-013-0489-x

Faye, B., Bengoumi, M., Cleradin, A., Tabarani, A. and Chilliard, Y., 2001. Body condition score in dromedary camel: A tool for management of reproduction, Emirates Journal of Agricultural Science, 13, $01--06$

Freire, R., Buckley, P., Cooper, J.J., 2009. Effects of different forms of exercise on post inhibitory rebound and unwanted behaviour in stabled horses. Equine veterinary journal, 41, 487-492. 
Haskell, M.J., Maslowska, K., Bell, D.J., Roberts, D.J. and Langford, F.M., 2013. The effect of a view to the surroundings and microclimate variables on use of a loafing area in housed dairy cattle. Applied Animal behavior Science, 147, 28--33

Hoyer, B.H., 2013. 'Environmental enrichment'- Strategies to improve the housing conditions of breeding bulls. Impact on time budget, physical activity, rumination, sexual behavior and semen quality, Thesis Doctor of Veterinary Medicine, University of Veterinary Medicine Hannover, Foundation, $160 \mathrm{p}$

Kataria, N., Kataria A.K.,, 2010. Can prolactin be a measurable marker of stress in dromedaries?, Slovenian Veterinary Research, 47, (3), 133--138

Kataria, A.K., Kataria, N., Maan, R., 2010. Correlation of serum IgE with stress in Indian dromedaries affected with skin wounds. Journal of Stress Physiology and Biochemistry, 6, (3), 17--24

Khan, B.B., Iqbal, A., Riaz, M., 2003. Production and management of camels: Part I, (University of agriculture Faisalabad)

Kirby, E.D., Geraghty, A.C., Ubuka, T., Bentley G.E., Kaufer, D., 2009. Stress increases putative gonadotropin inhibitory hormone and decreases luteinizing hormone in male rats, Proceedings of the National Academy of Science of the United States of America, 106, (27), 11324--11329

Laudadio, V., Tufarelli, V., Dario, M., Hammadi, M., Seddik, M.M., Lacalandra, G.M. and Dario, C., 2009. A survey of chemical and nutritional characteristics of halophytes plants used by camels in Southern Tunisia, Tropical Animal Health Production, 41, 209--215

McDonnell, S.M., 1986. Reproductive behavior of stallions. Equine Practice 2,(3), 535--555

McDonnell, S.M., 2000. Reproductive behavior of stallions and mares: comparison of free-running and domestic inhand breeding, Animal Reproduction Science, 60-61, 211--219

McGlone, J.J., Borell, H.V., Deen, J., Johnson, A.K., Levis, D.G., Meunier-Salaun, M., Morrow, J., Reeves, D., SlakJohnson, J.L. and Sundberg, P.L., 2004. Review: Compilation of the scientific literature comparing housing systems for gestating sows and gilts using measures of physiology, behavior, performance, and health,The Professional Animal Scientist, 20, 105--117

Morgan, K.N. and Tromborg, C.T., 2007. Sources of stress in captivity, Applied Animal Behavior Science, 102, $262--$ 302

Orr, T.E., Taylor, M.F., Bhattacharyya, A.K., Collins, D.C., Mann, D.R., 1994. Acute immobilization stress disrupts testicular steroidogenesis in adult male rats by inhibiting the activities of $17 \alpha$ - hydroxylase and 17, 20-lyase without affecting the binding of LH/hCG receptors, Journal of Andrology, 15, 302--308 
Padalino, B., Fatnassi, M., Monaco, D., Hammadi, M., Khorchani, T. and Lacalandra, G.M., 2013. A new ethogram for evaluating housed male dromedary camel behavior and libido, Proceeding of the XI congress of Italian Society of Animal Reproduction (SIRA), Ustica, Italy, 137--142

Padalino, B., Aubé, L., Fatnassi, M., Monaco, D., Khorchani, T., Hammadi, M. and Lacalandra, M.G., 2014. Could dromedary camels develop stereotypy? The first description of stereotypical behaviour in housed male dromedary camels and how it is affected by different management systems. PLOS ONE (accepted for publication)

Phillips, D.M., Lakshmi, V. and Monder, C., 1989. Corticosteroid 11 $\beta$-dehydrogenase in rat testis, Endocrinology, 125 , 209--216

Retana-Marquez, S., Bonilla-Jaime, H., Vazquez-Palacios, G., Matrinez-Garcia, R., Velazquez-Moctezuma, J., 2003. Changes in masculine sexual behavior, corticosterone and testosterone in response to acute and chronic stress in male rats, Hormones and Behaviour, 44, 327--337

Rivier, C., Rivest, S., 1991. Effect of stress on the activity of the hypothalamic-pituitary-gonadal axis: Peripheral and central mechanisms, Biology of Reproduction, 45, 523--532

SAS, 9th version, 1999. The SAS System for Windows, Release 9.00. SAS Institute Inc., Cary, NC

Schwan, L., 2011. Social behavior and time budget of breeding bulls, (Student report,Swedish University of Agricultural Sciences)

Skidmore, J.A., 2000. Reproductive Physiology in Male and Female Camels. In: Recent advances in camelid reproduction. Skidmore J.A. and Adams,G.P., (eds), (Publisher: International Veterinary Information Service, Ithaca, New York, USA)

Skidmore, J.A., Morton, K.M. and Billah, M., 2013. Artificial Insemination in Dromedary Camels, Animal Reproduction Science, 136, 178--186

Spinka, M., 2006. How important is natural behavior in animal farming systems? Applied Animal Behviour Science, $100,117--128$

Stout, T.A.E., 2005. Modulating reproductive activity in stallions: A review Animal Reproduction Science, 89, 93--103

Vyas, S., Pareek, P. K., Purohit, G. N. and Sahani, M. S., 2001. Management practices for augmenting rut in male (Camelus dromedarius), Veterinary Practitioner, 2, 132--34

Wingfield, J. C. and Sapolsky, R. M. 2003. Reproduction and resistance to stress: when and how, Journal of neuroendocrinology, 15, 711--724

Yagil, R. and Etzion, Z., 1980. Hormonal and behavioural patterns in the male camel (Camelus dromedarius), Journal of reproduction and Fertility, 58, 61--65 
Fig. 1Average plasma cortisol concentration $(\mathrm{ng} / \mathrm{ml})$ in housed male dromedary camel $(\mathrm{n}=4)$ in the three different management systems: housed in a single stall for 24 hours (H24), housed in a single stall for 23 hours and one hour in a paddock (H23), housed in a single stall for 22 hours and 30 minutes, one hour in a paddock and 30 minutes of female exposure(ExF)

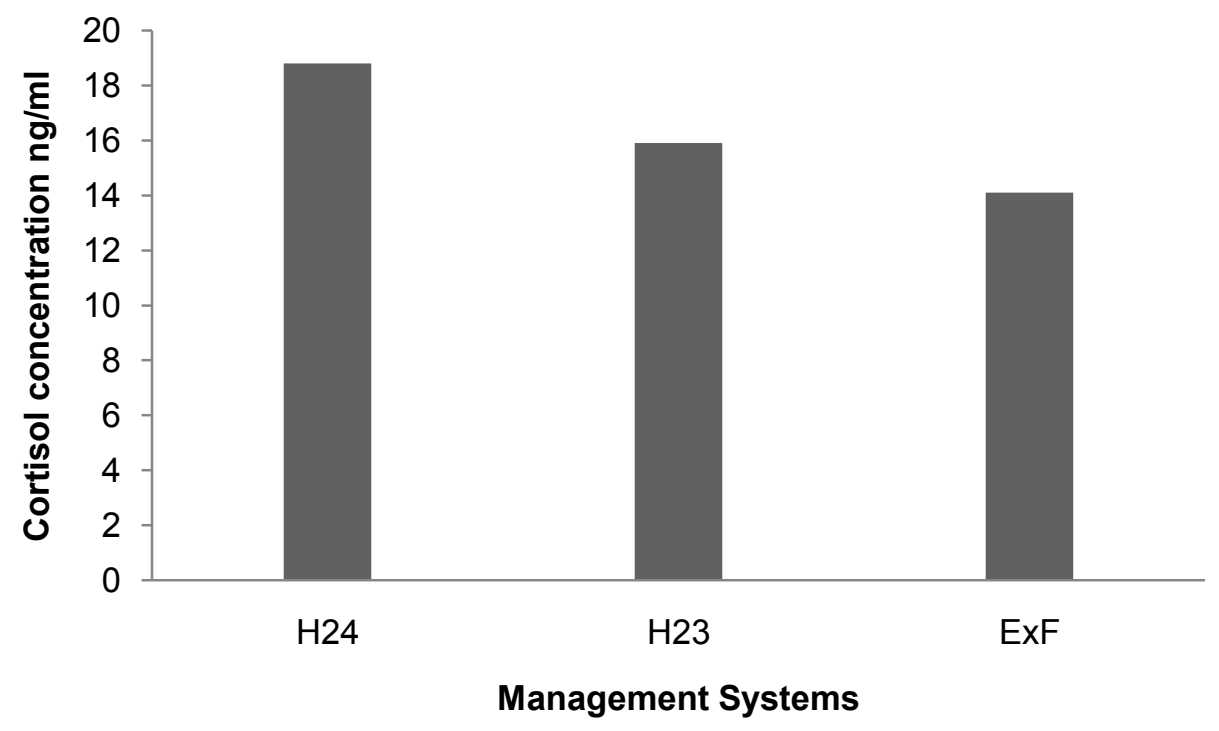


Fig. 2 Behavioral states recorded during 30 minutes of observation period mornings in housed male dromedary camels $(n=4)$ in three different management systems:: housed in a single stall for 24 hours $(\mathrm{H} 24)$, housed in a single stall for 23 hours and one hour in a paddock (H23), housed in a single stall for 22 hours and 30 minutes, one hour in a paddock and 30 minutes of female exposure(ExF)

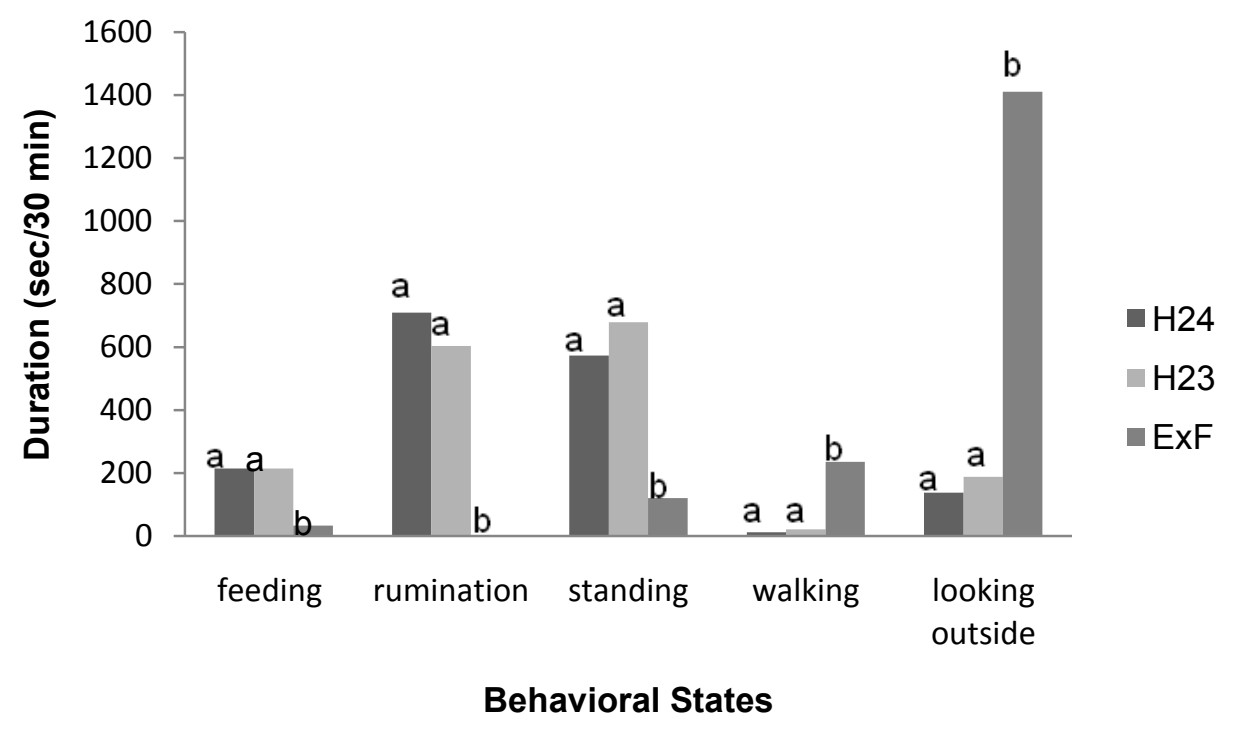

${ }^{\mathrm{a}, \mathrm{b}}$ differ significantly $(\mathrm{P}<0.01)$ 
Fig. 3 Sexual behavioral scored (from 1 to 5, by Padalino et al. (2013)) after female passage in the evening in housed male dromedary camels $(n=4)$ in three different management systems: housed in a single stall for 24 hours (H24), housed in a single stall for 23 hours and one hour in a paddock (H23), housed in a single stall for 22 hours and 30 minutes, one hour in a paddock and 30 minutes of female exposure(ExF)

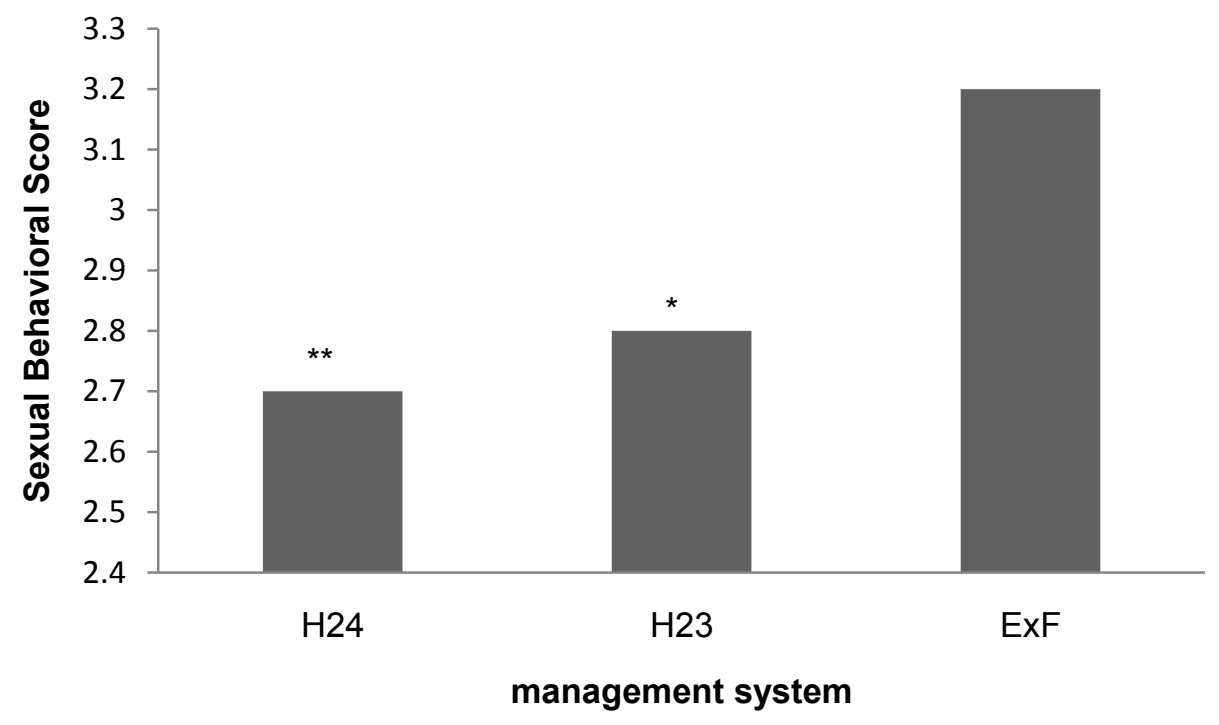

${ }^{* *}$ differ significantly $(\mathrm{P}<0.01) ;{ }^{*}$ differ significantly $(\mathrm{P}<0.05)$ 
Table 1 Chemical composition ( $\%$ on dry matter basis) of oat hay and concentrate fed to camels during the experimental period.

\begin{tabular}{lrc}
\hline & Oat Hay & Concentrate \\
\hline Dry Matter & 90.0 & 90.9 \\
Crude Protein & 6.8 & 11.4 \\
Crude Fiber & 48.9 & 20.5 \\
Neutral detergent Fibre & 55.8 & 31.6 \\
Acid detergent Fiber & 35.1 & 16.3 \\
Lignin & 5.7 & 3.2 \\
Ether Extract & 2.0 & 4.5 \\
Ash & 7.9 & 8.1 \\
\hline
\end{tabular}

Table 2 "Sexual Behavioral Score" for housed male dromedary camels during female passage (Padalino et al. 2013)

\begin{tabular}{ll}
\hline \multicolumn{1}{c}{ Behavioral Score } & \multicolumn{1}{c}{ Criteria } \\
\hline 1: not interested & The male does not show any sexual behavior parameters \\
2: low interested & The male goes near the female and shows a low frequency of sniffing and flehmen \\
3: interested & $\begin{array}{l}\text { The male goes near the female and shows sniffing, flehmen, grinding of teeth/ } \\
\text { whistling, yawning }\end{array}$ \\
4: high interested & $\begin{array}{l}\text { The male goes near the female and shows sniffing, flehmen, grinding of teeth/ } \\
\text { whistling, yawning (more than 3), urination and tail raising. He is very agitated, } \\
\text { stands with open legs, poll gland secretion and neck rubbing are observed }\end{array}$ \\
As in 4, but the male shows blatering and dulaa extrusion, is very excited, stands \\
with open legs, high poll gland secretion and neck rubbing are observed
\end{tabular}

Table 3Least square means $( \pm \mathrm{SE})$ of behavioral parameters occurrence $((\mathrm{n} / 30 \mathrm{~min})$ in housed male dromedary camels $(n=4)$ in three different management systems:housed in a single stall for 24 hours (H24), housed in a single stall for 23 hours and one hour in a paddock (H23), housed in a single stall for 22 hours and 30 minutes, one hour in a paddock and 30 minutes of female exposure (ExF)

\begin{tabular}{lccc}
\hline Behavior & H24 & $\mathbf{H 2 3}$ & ExF \\
\hline Leg movement frequency & $36.7 \pm 4.0^{\mathrm{b}}$ & $35.0 \pm 4.0^{\mathrm{b}}$ & $92.5 \pm 4.0^{\mathrm{a}}$ \\
Number of steps & $47.5 \pm 15.5^{\mathrm{b}}$ & $27.1 \pm 15.5^{\mathrm{b}}$ & $240.2 \pm 15.5^{\mathrm{a}}$ \\
Sound emission frequency & $0.1 \pm 2.5^{\mathrm{b}}$ & $0.1 \pm 2.5^{\mathrm{b}}$ & $11.5 \pm 2.5^{\mathrm{a}}$ \\
Defecation frequency & $0.5 \pm 0.2^{\mathrm{b}}$ & $0.2 \pm 0.2^{\mathrm{b}}$ & $2.3 \pm 0.2^{\mathrm{a}}$ \\
Urination frequency & $0.1 \pm 0.3^{\mathrm{b}}$ & $0.1 \pm 0.3^{\mathrm{b}}$ & $2.5 \pm 0.3^{\mathrm{a}}$ \\
Tail Flapping & $0.5 \pm 0.2^{\mathrm{b}}$ & $0.5 \pm 0.2^{\mathrm{b}}$ & $9.2 \pm 3.0^{\mathrm{a}}$ \\
Open leg frequency & $1.4 \pm 0.6^{\mathrm{b}}$ & $1.2 \pm 0.6^{\mathrm{b}}$ & $5.5 \pm 0.6^{\mathrm{a}}$ \\
Yawning & $0.8 \pm 0.5^{\mathrm{b}}$ & $0.5 \pm 0.5^{\mathrm{b}}$ & $4.4 \pm 0.5^{\mathrm{a}}$ \\
Teeth Grinding & $3.6 \pm 2.4^{\mathrm{b}}$ & $2.7 \pm 2.4^{\mathrm{b}}$ & $37.3 \pm 2 .^{\mathrm{a}}$ \\
Blatering & $0.1 \pm 1.1^{\mathrm{b}}$ & $0.1 \pm 1.1^{\mathrm{b}}$ & $11.5 \pm 1.1^{\mathrm{a}}$ \\
Sniffing & $0.2 \pm 0.5^{\mathrm{b}}$ & $0.1 \pm 0.1^{\mathrm{b}}$ & $14.9 \pm 1.4^{\mathrm{a}}$ \\
Flehmen & $0.1 \pm 0.7^{\mathrm{b}}$ & $0.1 \pm 0.7^{\mathrm{b}}$ & $6.6 \pm 0.7^{\mathrm{a}}$ \\
\hline
\end{tabular}

${ }^{\mathrm{a}, \mathrm{b}}$ Least square means $( \pm \mathrm{SE})$ in each column with no common superscript differ significantly $(\mathrm{P}<0.01)$ 